OPEN ACCESS

Edited by:

Télesphore Sime-Ngando, Centre National de la Recherche

Scientifique (CNRS), France

Reviewed by:

Dag O. Hessen,

University of Oslo, Norway Michael Danger,

Université de Lorraine, France

*Correspondence: André M. Amado amado@ufrnet.br

Specialty section: This article was submitted to Aquatic Microbiology,

a section of the journal

Frontiers in Microbiology

Received: 28 February 2017

Accepted: 27 July 2017

Published: 08 August 2017

Citation:

They NH, Amado AM and Cotner JB (2017) Redfield Ratios in Inland

Waters: Higher Biological Control of C:N:P Ratios in Tropical Semi-arid High Water Residence Time Lakes.

Front. Microbiol. 8:1505.

doi: 10.3389/fmicb.2017.01505

\section{Redfield Ratios in Inland Waters: Higher Biological Control of C:N:P Ratios in Tropical Semi-arid High Water Residence Time Lakes}

\author{
Ng H. They ${ }^{1}$, André M. Amado ${ }^{1,2 *}$ and James B. Cotner ${ }^{3}$ \\ 1 Graduate Program in Ecology, Limnology Laboratory, Department of Oceanography and Limnology, Universidade Federal \\ do Rio Grande do Norte, Natal, Brazil, ${ }^{2}$ Department of Biology, Universidade Federal de Juiz de Fora, Juiz de Fora, Brazil, \\ ${ }^{3}$ Department of Ecology, Evolution, and Behavior, University of Minnesota, St. Paul, MN, United States
}

The canonical Redfield C:N:P ratio for algal biomass is often not achieved in inland waters due to higher $\mathrm{C}$ and $\mathrm{N}$ content and more variability when compared to the oceans. This has been attributed to much lower residence times and higher contributions of the watershed to the total organic matter pool of continental ecosystems. In this study we examined the effect of water residence times in low latitude lakes (in a gradient from humid to a semi-arid region) on seston elemental ratios in different size fractions. We used lake water specific conductivity as a proxy for residence time in a region of Eastern Brazil where there is a strong precipitation gradient. The C:P ratios decreased in the seston and bacterial size-fractions and increased in the dissolved fraction with increasing water retention time, suggesting uptake of $N$ and $P$ from the dissolved pool. Bacterial abundance, production and respiration increased in response to increased residence time and intracellular nutrient availability in agreement with the growth rate hypothesis. Our results reinforce the role of microorganisms in shaping the chemical environment in aquatic systems particularly at long water residence times and highlights the importance of this factor in influencing ecological stoichiometry in all aquatic ecosystems.

Keywords: nutrients, metabolism, bacteria, ecological stoichiometry, semi-arid, tropical, lakes, water residence time

\section{INTRODUCTION}

Life has had a strong impact in influencing the availability of elements on the Earth. About 2.3 billion years ago the atmosphere was drastically changed to an oxidative state with the rise of $\mathrm{O}_{2}$ and fall of $\mathrm{CO}_{2}$ concentrations that were preceded by the 'invention' of photosynthesis (Kasting and Siefert, 2002). As the redox state of the Earth changed, organisms had to adapt to the changing steady state. Similar processes occur in the oceans today, whereby micro-organisms alter their external chemical environment, which is reflective of their own elemental biomass composition, i.e., stoichiometry. The mean elemental composition of ocean plankton with respect to the macroelements carbon $(\mathrm{C})$, nitrogen $(\mathrm{N})$ and phosphorus $(\mathrm{P})$ was first discussed by Redfield $(1934,1958)$ and the ratio of 106C: $16 \mathrm{~N}$ : $1 \mathrm{P}$ is referred today as the 'Redfield ratio.' 
In marine waters, it is now clear that there is variability around the Redfield ratio due to latitudinal changes and nutrient availability effects (Martiny et al., 2013), whereas in inland waters the $\mathrm{C}: \mathrm{N}: \mathrm{P}$ ratios are often higher in magnitude and with greater variability (Hecky et al., 1993; Hassett et al., 1997; Sterner et al., 2008). The seston C:N:P ratios are influenced by species composition (e.g., eukaryotes vs. prokaryotes, N-fixing cyanobacteria, diatoms, etc.), temperature, organic matter inputs (quality and quantity), light:nutrient ratio, total $\mathrm{P}$, chlorophyll, POC (particulate organic carbon): chlorophyll ratio and water residence time (WRT) (Hecky et al., 1993; McGroody et al., 2004; Hessen, 2006; Geider and La Roche, 2002; Martiny et al., 2013). Particularly in inland waters, it is often assumed that the income of large amounts of organic matter from terrestrial environments with typically high $\mathrm{C}: \mathrm{N}: \mathrm{P}$ ratios, as well as a variable share of phytoplankton (autochthonous production) relative to total seston (Hessen et al., 2003), and a tendency of lower environmental stability in space and time could cause the great variability in the seston elemental ratios when compared to the oceans (but see Hessen et al., 2003 and Hessen, 2006).

The residence times of substances in the oceans are quite long. The water has a residence (WRT) time of $>3,000$ years on average, while $\mathrm{NO}_{3}{ }^{-}$and $\mathrm{PO}_{4}{ }^{3-}$ have a much longer residence time ( $\sim 10^{4}$ years) (Falkowski and Davis, 2004). In contrast, in inland waters the WRT can be as low as days to 10s of 1000s years (Bell et al., 2002), but are typically much shorter than in the oceans. The residence times of elements such as $\mathrm{P}$ are comparable to WRT, usually less than a year to a few years (Sonzogni et al., 1976). Nitrogen retention time also is highly dependent on WRT, but has a more complex cycle and its retention depends on the type and abundance of vegetation, nitrification and denitrifications rates (Saunders and Kalff, 2001). Even though it has been debated about the general applicability of the classical Redfield ratio in the oceans (Koeve and Kähler, 2010; Martiny et al., 2013) and organisms (Geider and La Roche, 2002), the central tenet of Redfield's idea remains valid today (Falkowski and Davis, 2004; Gruber and Deutsch, 2014).

Microbes including virus, archaea, autotrophic and heterotrophic bacteria and algae play a central role in shaping aquatic ecosystem nutrient ratios (e.g., C, N, and P) and bacteria are the major consumers of $\mathrm{P}$ and $\mathrm{N}$-based compounds in both marine and inland waters (Kirchman, 1994; Cotner and Biddanda, 2002). Nutrient concentrations and availability in the water column in turn also affect bacteria through constraints on metabolism and biomass composition. Bacteria growing under P-rich conditions (expressing high growth rates) are expected to exhibit low biomass C:P. High growth rates are associated with major allocation of $\mathrm{P}$ for nucleic acids in ribosomes, which is known as the Growth Rate Hypothesis (GRH) (Elser et al., 1996). Conversely, when growing under P-limiting conditions bacteria may either present high C:P ratios in the biomass (Cotner et al., 2010; Godwin and Cotner, 2015) or exhibit high respiration rates (Cimbleris and Kalff, 1998), possibly as a mechanism to eliminate the excess carbon from organic matter and to concentrate the $\mathrm{P}$ to an adequate amount (Hessen and Anderson, 2008). However, bacteria can also take up inorganic nutrients directly from the water (Cotner and Wetzel, 1992; Kirchman, 1994), which could possibly explain a compensation for low quality (high C:nutrients) substrates.

Most studies on ecological stoichiometry have examined the whole seston rather than examining the different planktonic groups (e.g., phytoplankton and bacterioplankton size fractions) separately and usually ignore the dissolved organic matter fraction (but see Hessen et al., 2003). For instance, the dissolved organic matter fraction and bacteria fraction are not well studied despite accounting for the largest part of the organic matter in many aquatic ecosystems (Wetzel, 1984; Simon et al., 1992; Gasol et al., 1997). Moreover, differences are expected in terms of stoichiometric flexibility (ability to adjust the internal C:N:P compositions in relation to the sources) among the planktonic components. The zooplankton have been reported to be quite inflexible, (Andersen and Hessen, 1991; Persson et al., 2010; Godwin and Cotner, 2015) and the phytoplankton community is more variable and more flexible (Geider and La Roche, 2002), responding to a wide gradient of light:nutrients ratios (Sterner et al., 1997; Hessen et al., 2002). However, a recent study has shown that the bacterial community can be the most flexible group of heterotrophic organisms known so far (Godwin and Cotner, 2015), with a high potential for adjusting and affecting environmental nutrient availability. The dissolved organic nutrient pools can buffer fluctuations in planktonic nutrient requirements depending on the rate of supply from external environments and their nutrient ratios. Heterotrophic bacteria grow relatively fast and consume primarily dissolved pools of inorganic and organic matter and thus are an important factor determining the elemental stoichiometry of both the dissolved and particulate pools.

The great variability in residence time in inland water ecosystems relative to oceans may be a key feature explaining the departure of freshwaters from Redfield ratios, i.e., a higher decoupling between bacteria and their substrates in inland water ecosystems due to variable WRT. To examine this hypothesis, we tested the effect of increasing WRT on the stoichiometry of seston, bacterial and dissolved fractions, as well as on bacterial metabolism in low latitude coastal and semi-arid lakes encompassing a wide range of trophic states and WRT. The sampling of aquatic systems in Eastern Brazil coincided with a strong El Niño event that began in June 2014 and extended through 2016. ${ }^{1}$ This phenomenon is associated with droughts in Northeastern Brazil, particularly in the semi-arid zone (Rodrigues et al., 2011). Semi-arid lakes in eastern Brazil may experience extended periods of drought and high rates of water evaporation. Since these semi-arid lakes receive only the contribution of intermittent rivers, the inflow rates are negligible (close to zero) during drought, particularly for severe episodes such as the El Niño period that occurred during this study. Hence, drought has then an indirect effect on increasing WRT. This is paralleled by increasing concentrations of nutrients and increased specific conductivity, which in turn may be used as a proxy for WRT (Curtis and Adams, 1995; Rennella and Quirós, 2006; Anderson and Stedmon, 2007).

${ }^{1}$ http://www.bom.gov.au/climate/enso/\#tabs=SOI 


\section{MATERIALS AND METHODS}

\section{Study Area}

We sampled 15 ecosystems that consisted of both natural lakes and artificial reservoirs located in northeastern Brazil in Rio Grande do Norte state that encompass a trophic gradient ranging from oligotrophy to hypereutrophy and a wide range of environmental conditions (Table 1). These ecosystems are found in a relatively narrow latitudinal (from $06^{\circ} 24^{\prime} 36.5^{\prime \prime} \mathrm{S}$ to $06^{\circ} 41^{\prime} 42.9^{\prime \prime} \mathrm{S}$ ) and longitudinal (from $35^{\circ} 05^{\prime} 59.4^{\prime \prime} \mathrm{W}$ to $\left.36^{\circ} 37^{\prime} 43.6^{\prime \prime} \mathrm{W}\right)$ range that, nonetheless encompass a strong climatic gradient from the humid coastal zone (oligo- to mesotrophic lakes) to the inner, semi-arid zone (mostly eutrophic lakes and with longer WRT).

The coastal region climate is classified as humid with average annual temperature above $26^{\circ} \mathrm{C}$. The historical annual average precipitation is $1,230 \mathrm{~mm}$ with $90 \%$ of rainfall between January and August. The vegetation in this area is classified as Atlantic rain forest (see Cestaro and Soares, 2004), which contributes with significant organic matter to aquatic ecosystems in the rainy season (Kosten et al., 2010). The inner region climate is classified as tropical and semi-arid (BS'h' according to Kottek et al., 2006) with annual average temperature higher than $25^{\circ} \mathrm{C}$. It is characterized by irregular rainfall, high evapotranspiration rates, and negative water balance during most of the year, particularly in the last 3 years. The mean annual precipitation is $733 \mathrm{~mm}$ in the previous 20 years and the aquatic ecosystems have long residence times (e.g., water residence time calculated in 2004 from 780 days in Boqueirão reservoir to 1460 days in Gargalheiras reservoir, both sampled in the current study; Chellappa et al., 2009). However, the annual precipitation was below the average (between 200 and $600 \mathrm{~mm}$ per year) and the aquatic ecosystems have experienced extreme droughts since 2012 (Costa et al., 2016). Because of that, these ecosystems have experienced extreme reductions in volume (Medeiros et al., 2015).

\section{Sampling}

Each lake was sampled once close to its central point between October and December in 2014. In each lake, $10 \mathrm{~L}$ of subsurface water $(20-30 \mathrm{~cm})$ was collected in acid-rinsed $(\mathrm{HCl} 10 \%)$ polyethylene bottles. The water transparency was determined with a secchi disk and the temperature and conductivity were measured in situ using a multi-parameter probe (Horiba U22). The depth of the sampling point was determined with a depth meter or manually with a weight tied to a rope. Two subsamples were taken in plastic bottles without headspace for the determination of alkalinity. All samples were processed within $24 \mathrm{~h}$; when the time between sampling and handling exceeded $4 \mathrm{~h}$, the samples were kept refrigerated.

\section{Limnological Variables and Fractionation}

In the laboratory, the $\mathrm{pH}$ (Hanna HI-221) and alkalinity by Gran titration $\left(\mathrm{H}_{2} \mathrm{SO}_{4} 0.0125 \mathrm{M}\right)$ were immediately measured. The water was fractionated by sequential filtration through $1.6 \mu \mathrm{m}$ mean retention pore-size glass fiber filters (Whatman

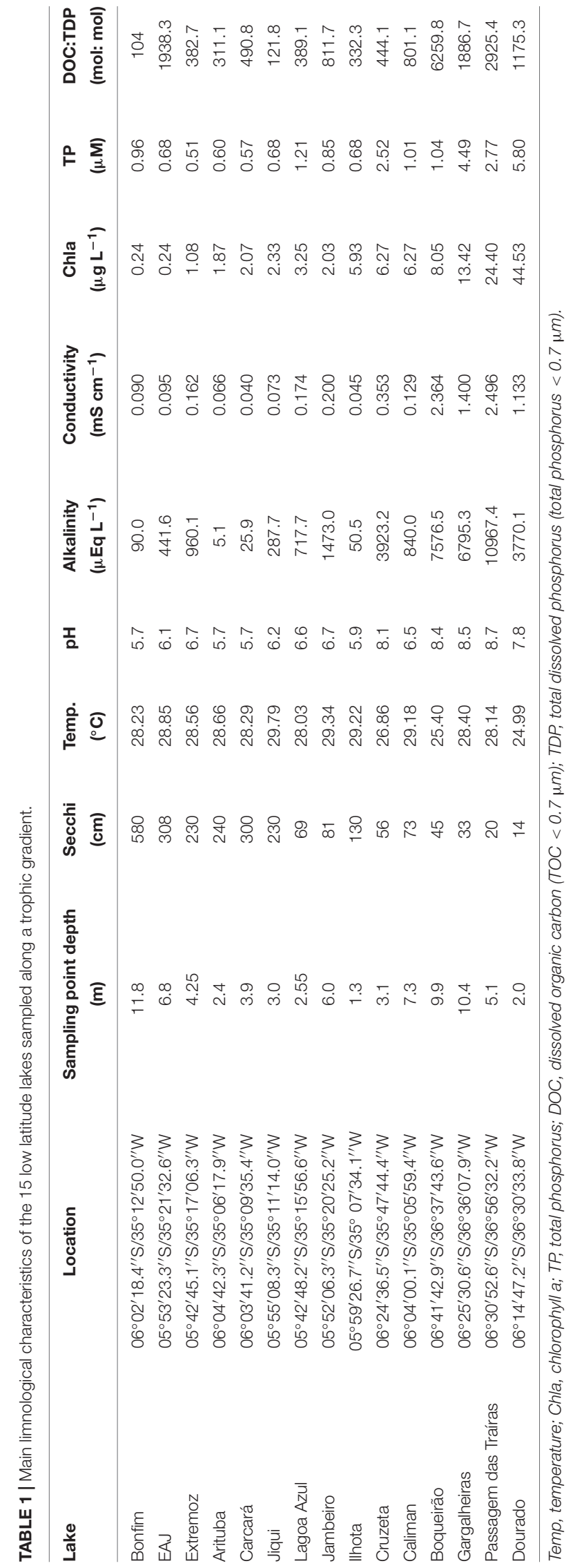




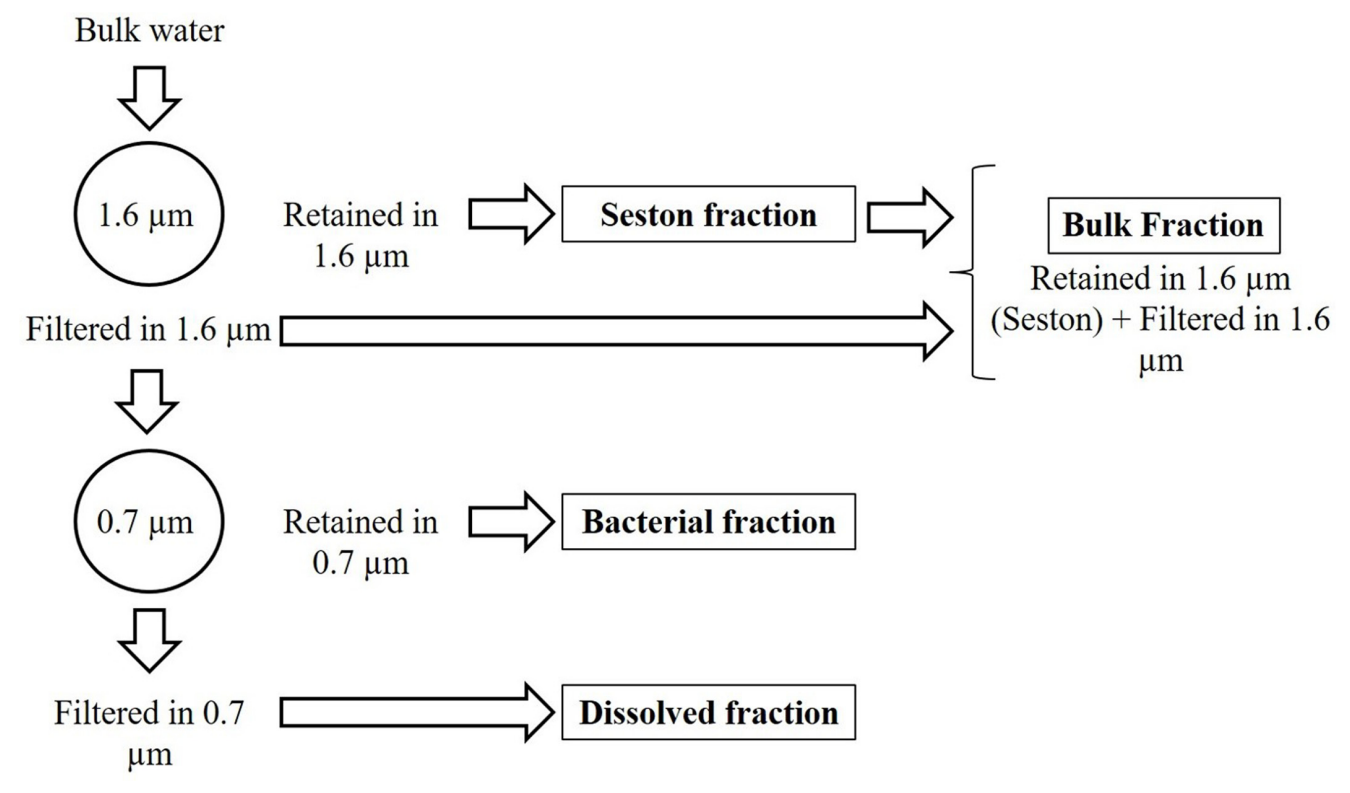

FIGURE 1 | Scheme of the size fractionation of the water.

$\mathrm{GF} / \mathrm{A}$ ) and $0.7 \mu \mathrm{m}$ mean retention pore-size glass fiber filters (Whatman GF/F). This procedure was adopted to separate the seston (here assumed as $>1.6 \mu \mathrm{m}$ ), bacterial (here assumed as particles between 1.6 and $0.7 \mu \mathrm{m}$ ) and dissolved fractions (here assumed as $<0.7 \mu \mathrm{m}$ ). The bulk fraction was estimated as the sum of seston $(>1.6 \mu \mathrm{m})$ and the $<1.6 \mu \mathrm{m}$ fraction (Figure 1). The bacterial fraction possibly includes archaeal cells, but since Archaea are in general a minor component (<6\%) of pelagic prokaryote communities (Glöckner et al., 1999), we refer to this fraction as bacteria. The 1.6-0.7 $\mu \mathrm{m}$ fraction included on average $79 \%$ of the bacteria. Even though the $0.7 \mu \mathrm{m}$ filter allowed some bacteria to pass, the glass fiber filter can be used for the analysis in the TOC equipment without interference of the filter components (such as $\mathrm{C}$ and $\mathrm{N}$ from $0.2 \mu \mathrm{m}$ porosity membrane filters often made of $\mathrm{C}, \mathrm{N}$ and P-containing polymers) and has been successfully employed in similar studies for the same purpose (Cotner et al., 2010). The bacterial density (BD) was determined in the bulk, bacterial and dissolved fractions (see below), and appropriate corrections were applied by estimating mean bacterial cell $\mathrm{C}, \mathrm{N}$, and $\mathrm{P}$ content in the bacterial fraction and summing up the nutrients amounts in the retained or filtered bacteria (Supplementary Table 1). It is noteworthy to mention that our understanding of the stoichiometry of bacteria is somewhat biased by the fact that we did not have appropriate tools for distinguishing the composition and abundance of free and attached bacteria, with the last being part of the seston. This should have a little impact on the results found, since typically attached bacteria represent a small proportion $(<30 \%)$ of the total bacterial pool (Simon, 1987).

Chlorophyll a was measured after filtration of bulk water through a $1.2 \mu \mathrm{m}$ mean retention pore size glass fiber filter (GF/C Whatman). The filters were kept at $-80^{\circ} \mathrm{C}$ and the chlorophyll $a$ was extracted with ethanol (90\%) at $-20^{\circ} \mathrm{C}$ in the dark (Nusch and Palme, 1975; APHA, 1999). The chlorophyll was measured without acidification at $665 \mathrm{~nm}$ after correction for turbidity (750 nm) and calculated according to Salonen and Sarvala (1995) and Schilling et al. (2006).

\section{$C, N$, and $P$}

In the four water fractions, we measured the total $\mathrm{C}$, total $\mathrm{N}$, and total $\mathrm{P}$ concentrations. The total and filtered (dissolved) fractions of the organic carbon (TOC and DOC) and nitrogen (TN and DN) were measured in a Total Organic Carbon Analyzer (TOCV CPN Shimadzu). The different fractions of particulate organic carbon in the filters were measured using the solid sample module (SSM-5000 A) of the TOC analyzer. Particulate nitrogen and phosphorus on the filters and total phosphorus (TP) in the liquid samples were measured after potassium persulfate digestion (Carmouze, 1994). After digestion, the TN was measured in the TOC-V CPN (Shimadzu), whereas the TP was measured spectrophotometrically (SP2000UV) by the ascorbic acid method (Mackereth et al., 1978). All filters were combusted $\left(550^{\circ} \mathrm{C}\right.$ for $4 \mathrm{~h}$ ) prior to filtration and after the filtration and before the analysis were oven dried $\left(60^{\circ} \mathrm{C}\right.$ for $\left.>24 \mathrm{~h}\right)$ and weighed.

All bulk seston, bacteria and dissolved C:N, C:P, and N:P ratios were calculated on a molar basis (mol: mol).

\section{Bacterial Density and Metabolism}

The $\mathrm{BD}$ was estimated in the bulk, $<1.6$ and $<0.7 \mu \mathrm{m}$ fractions via flow cytometry, which allowed the determination of the number of cells in each fraction and the number of cells retained on the filters. The samples were fixed with buffered formaldehyde ( $4 \%$ final concentration) and kept at $-80^{\circ} \mathrm{C}$ until analysis in a BD FACSCalibur flow cytometer (within 5-8 months). The cells were stained with Syto 13 and the cytograms analyzed in the FlowJo X 
10.0.7r2 software (Gasol and Del Giorgio, 2000; Sarmento et al., 2008).

Bacterial production (BP) was measured via the $\left[{ }^{3} \mathrm{H}\right]$-leucine incorporation and microcentrifugation method (Smith and Azam, 1992), incubating bulk water samples for $2.5 \mathrm{~h}$. We assumed the molar percentage of leucine in the protein pool was equal to 0.073 , the intracellular isotopic dilution was equal to 2 and a carbon:protein ratio of 0.86 .

Bacterial respiration rates (BR) were measured in the $<1.6 \mu \mathrm{m}$ filtered water by following the oxygen consumption in $6 \mathrm{~mL}$ exetainer vials without headspace in the dark over variable periods of time (incubations were terminated when $\mathrm{O}_{2}$ concentrations were $\leq 8 \%$ of initial $\mathrm{O}_{2}$ concentrations; from 12 to $72 \mathrm{~h}$ of incubation). The oxygen concentrations were measured with a gold tip microprobe connected to a OXY-Meter (UNISENSE) and were converted to carbon using a respiratory quotient $=1.0$ (Briand et al., 2004).

Specific bacterial production and respiration (BP and BR $\mathrm{cell}^{-1}$ ) were calculated by dividing the respiration rates from each lake by the number of cells in the bulk and $<1.6 \mu \mathrm{m}$ fractions, respectively. The bacterial carbon demand was calculated as the sum of BP and BR (Alonso-Sáez et al., 2007).

\section{Statistical Analysis}

The $\log _{10}$ of the absolute concentrations of $\mathrm{C}, \mathrm{N}$, and $\mathrm{P}(\mu \mathrm{M})$ were linearly regressed against each other and compared to the expected Redfield ratios (106:16:1) by ANCOVA. Significant interactions indicated differences in slopes and significant intercepts indicated differences in the magnitude of the ratios.

The $\log _{10}$ of the C:N:P ratios of seston, bacteria and the dissolved fractions and of $\mathrm{BP}, \mathrm{BP}$ cell $^{-1}, \mathrm{BR}, \mathrm{BR}$ cell $^{-1}$, BGE $(\mathrm{BP} /[\mathrm{BP}+\mathrm{BR}])$ and $\mathrm{BCD}(\mathrm{BP}+\mathrm{BR})$ were linearly regressed against conductivity in order to assess the effect of residence time on the variation of these ratios, assuming conductivity as a proxy of water residence time (Rennella and Quirós, 2006; Anderson and Stedmon, 2007).

The $\log _{10}$ of the $\mathrm{BD}, \mathrm{BP}, \mathrm{BR}, \mathrm{BGE}$, and $\mathrm{BCD}$ were also linearly regressed against $\log _{10}$ of the bacterial C:N, C:P, and $\mathrm{N}: \mathrm{P}$ ratios in order to determine whether the bacterial internal stoichiometry was coupled to bacterial metabolism. Conversely, the bacterial C:N, C:P, and N:P ratios were linearly regressed against potential substrates (seston and dissolved) C:N, C:P, and $\mathrm{N}: \mathrm{P}$ ratios, respectively, in order to determine whether the substrate stoichiometry of these pools were correlated.

All statistics were carried out in R 3.2.2. (R Core Team, 2016) and all regressions assumptions were tested with the gvlma package (Pena and Slate, 2014).

\section{RESULTS}

The C:N:P ratios were variable for all fractions with means across all lakes being higher than expected by the classical Redfield ratio (mean seston C:N:P = 771:59:1; mean bacterial C:N:P = 320:34:1; mean dissolved C:N:P = 1225:173:1). Considering the extreme values, the lowest ratios were found in the bacterial fraction
(90:19:1) and the highest in the dissolved fraction (1225:173:1; Table 2).

All bivariate regressions between the absolute concentrations of $\mathrm{C}, \mathrm{N}$, and $\mathrm{P}$ of all fractions were positive and significant ( $\mathrm{C}$ to $\mathrm{N}$; $\mathrm{C}$ to $\mathrm{P} ; \mathrm{N}$ to $\mathrm{P}$ ), except for $\mathrm{C} \times \mathrm{P}$ and $\mathrm{N} \times \mathrm{P}$ of the dissolved fraction $(P>0.05)$ (Table 3). The comparison via ANCOVA of these relationships with those expected by the Redfield ratio revealed differences for all fractions with the exception of the dissolved $\mathrm{C} \times \mathrm{P}$ and $\mathrm{N} \times \mathrm{P}$. All seston measured slopes and the bacterial $\mathrm{C} \times \mathrm{P}$ and $\mathrm{N} \times \mathrm{P}$ slopes were higher than Redfield ratios, whereas the bacterial $\mathrm{C} \times \mathrm{N}$ and the dissolved $\mathrm{C} \times \mathrm{N}$ slopes were lower than Redfield. The intercepts of these regressions were also significantly higher than zero, except for seston and bacterial $\mathrm{C} \times \mathrm{N}$, the bacterial $\mathrm{N} \times \mathrm{P}$ and the dissolved $\mathrm{C} \times \mathrm{P}$ and $\mathrm{N} \times \mathrm{P}$ intercepts (Table 3 and Figure 2).

The seston C:N and C:P ratios decreased significantly with water conductivity, and the bacterial C:P followed the same pattern, although with a marginally insignificant relationship $(P=0.082)$ (Figures 3A-C). The dissolved organic C:P and $\mathrm{N}: \mathrm{P}$, however, increased with increasing conductivity (Figures 3D,E). All other regressions of C:N:P of the fractions (Seston N:P, Bacterial C:N and $\mathrm{N}: \mathrm{P}$, and dissolved organic $\mathrm{C}: \mathrm{N}$ ) with conductivity were not significant (not shown).

$\mathrm{BP}, \mathrm{BP}$ cell $^{-1}, \mathrm{BD}$ and $\mathrm{BCD}$ increased with specific conductivity (Figures $4 \mathrm{~A}, \mathrm{~B}, \mathrm{D}, \mathrm{E}$ ), while $\mathrm{BR}$ cell $^{-1}$ displayed the opposite pattern, decreasing with conductivity (Figures $4 \mathrm{C}$ ).

$\mathrm{BD}, \mathrm{BP}$ and $\mathrm{BCD}$ were negatively correlated to bacterial C: $\mathrm{P}$ and $\mathrm{N}$ : $\mathrm{P}$ ratios (Figure 5). No significant relationships were found between BR or BR cell ${ }^{-1}$ and bacterial C:N:P ratios.

The C:N:P ratios in the dissolved organic pool and the seston pool had contrasting relationships when regressed against bacterial ratios. Bacterial C:P decreased with dissolved C:P (Figure 6A), whereas bacterial N:P increased with seston N:P (Figure 6B).

\section{DISCUSSION}

As expected for inland waters, the C:N:P ratios in the low-latitude lakes surveyed in the current study were mostly higher than the Redfield ratios. Nonetheless, seston ratios became more similar to Redfield ratios with increasing conductivity, with decreased $\mathrm{C}: \mathrm{N}$ and C:P ratios. We argue that specific conductivity is a useful proxy for WRT in these systems and therefore, longer WRT may provide microbiota greater opportunity to extract nutrients from dissolved organic materials. Consistent with this argument, we observed positive correlations between C:P and $\mathrm{N}: \mathrm{P}$ in the dissolved fraction (i.e., DOC:TDP and TDN:TDP) with increasing conductivity (Figure 3). We also observed faster specific growth rates in systems with higher conductivity (Figure 4), suggesting that part of the explanation for higher $\mathrm{P}$ content in systems with increased conductivity may have been the GRH (Sterner and Elser, 2002; Makino et al., 2003). Thus, we confirmed our hypothesis that the increasing WRT corresponded with decreased C:N and C:P in seston and bacterial biomass.

Our observations for freshwater seston stoichiometry in the tropics were similar to the mean seston estimates from a survey 


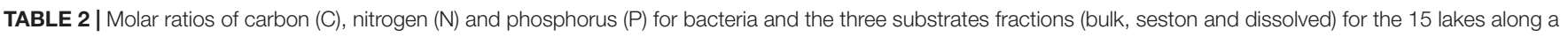
trophic gradient.

\begin{tabular}{|c|c|c|c|c|c|c|c|c|c|c|c|c|}
\hline \multirow[t]{2}{*}{ Lakes } & \multicolumn{3}{|c|}{$\begin{array}{c}\text { Bacterial per cell } \\
\text { (femtomol:femtomol) }\end{array}$} & \multicolumn{3}{|c|}{$\begin{array}{c}\text { Bulk (Seston }+<1.6 \mu \mathrm{m}) \\
(\mu \mathrm{mol}: \mu \mathrm{mol})\end{array}$} & \multicolumn{3}{|c|}{$\begin{array}{c}\text { Seston }(>1.6 \mu \mathrm{m}) \\
(\mu \mathrm{mol}: \mu \mathrm{mol})\end{array}$} & \multicolumn{3}{|c|}{$\begin{array}{c}\text { Dissolved }(<0.7 \mu \mathrm{m}) \\
(\mu \mathrm{mol}: \mu \mathrm{mol})\end{array}$} \\
\hline & $\mathrm{C}: \mathrm{N}$ & C:P & $N: P$ & C:N & C:P & $\mathrm{N}: \mathrm{P}$ & C:N & C:P & $N: P$ & C:N & C:P & $N: P$ \\
\hline Bonfim & 20.4 & 1675.3 & 82.1 & 11.5 & 156.3 & 13.6 & 8.1 & 431.7 & 53.1 & 14.6 & 104.0 & 7.1 \\
\hline EAJ & 5.0 & 286.2 & 57.0 & 14.9 & 766.5 & 51.4 & 13.0 & 1502.7 & 115.2 & 17.1 & 1938.3 & 113.5 \\
\hline Extremoz & 3.2 & 89.9 & 28.0 & 10.3 & 811.6 & 78.8 & 9.7 & 653.2 & 67.3 & 11.7 & 382.7 & 32.8 \\
\hline Arituba & 12.3 & 289.1 & 23.5 & 9.6 & 430.0 & 44.8 & 16.2 & 915.3 & 56.6 & 7.3 & 311.1 & 42.7 \\
\hline Carcará & 10.2 & 342.0 & 33.5 & 11.6 & 554.0 & 47.7 & 14.8 & 779.4 & 52.6 & 11.0 & 490.8 & 44.7 \\
\hline Jiqui & 13.9 & 262.5 & 18.9 & 1.1 & 247.3 & 228.4 & 19.9 & 683.4 & 34.4 & 0.6 & 121.8 & 197.7 \\
\hline Lagoa Azul & 8.1 & 395.6 & 48.9 & 1.5 & 902.8 & 584.4 & 13.5 & 2134.4 & 157.6 & 0.5 & 389.1 & 805.6 \\
\hline Jambeiro & 2.8 & 108.7 & 39.1 & 13.1 & 1113.4 & 85.2 & 14.7 & 651.6 & 44.4 & 12.8 & 811.7 & 63.6 \\
\hline Ilhota & 11.8 & 447.6 & 37.8 & 13.9 & 502.2 & 36.1 & 22.6 & 1350.8 & 59.9 & 10.2 & 332.3 & 32.7 \\
\hline Cruzeta & 8.0 & 212.9 & 26.6 & 10.9 & 350.5 & 32.0 & 10.1 & 233.7 & 23.2 & 11.8 & 444.1 & 37.7 \\
\hline "Caliman" & 7.4 & 148.7 & 20.1 & 15.2 & 563.6 & 37.1 & 19.2 & 681.8 & 35.6 & 12.9 & 801.1 & 61.9 \\
\hline Boqueirão & 5.2 & 163.7 & 31.3 & 10.5 & 1632.5 & 156.1 & 7.8 & 614.7 & 79.2 & 11.1 & 6259.8 & 565.5 \\
\hline Gargalheiras & 5.7 & 116.1 & 20.4 & 10.2 & 654.0 & 64.4 & 7.5 & 226.0 & 30.2 & 11.9 & 1886.7 & 158.7 \\
\hline Traíras & 6.3 & 164.0 & 26.3 & 9.3 & 1057.2 & 114.2 & 8.0 & 456.2 & 57.0 & 10.0 & 2925.4 & 293.6 \\
\hline Dourado & 9.3 & 220.1 & 23.6 & 12.0 & 565.1 & 47.1 & 11.3 & 244.2 & 21.5 & 8.6 & 1175.3 & 136.1 \\
\hline Mean & 8.5 & 319.9 & 34.5 & 10.4 & 687.1 & 108.1 & 13.1 & 770.6 & 59.2 & 10.1 & 1224.9 & 172.9 \\
\hline Min. & 2.8 & 89.9 & 18.9 & 1.1 & 156.3 & 13.6 & 7.5 & 226 & 21.5 & 0.5 & 104 & 7.1 \\
\hline Max. & 20.4 & 1675.3 & 82.1 & 15.2 & 1632.5 & 584.4 & 22.6 & 2134.4 & 157.6 & 17.1 & 6259.8 & 805.6 \\
\hline
\end{tabular}

TABLE 3 | Comparison of slopes and intercepts between measured and expected Redfield relationships of pairs of nutrients (carbon, C, nitrogen, N and phosphorus, P) for seston, bacterial and dissolved fractions for the 15 lakes along the trophic gradient.

\begin{tabular}{|c|c|c|c|c|c|c|}
\hline & \multicolumn{2}{|c|}{$\mathbf{C} \times \mathbf{N}$} & \multicolumn{2}{|c|}{$C \times P$} & \multicolumn{2}{|c|}{$\mathbf{N} \times \mathbf{P}$} \\
\hline & Measured & $P$-value & Measured & $P$-value & Measured & $P$-value \\
\hline \multicolumn{7}{|l|}{ Seston } \\
\hline slope & 9.22 & $<0.01$ & 218.11 & $<0.01$ & 22.80 & $<0.05$ \\
\hline intercept & 37.19 & $>0.05$ & 136.24 & $<0.05$ & 11.39 & $<0.05$ \\
\hline \multicolumn{7}{|l|}{ Bacteria } \\
\hline slope & 5.74 & $<0.05$ & 135.31 & $<0.05$ & 23.39 & $<0.0001$ \\
\hline intercept & 4.04 & $>0.05$ & 6.82 & $<0.05$ & 0.51 & $>0.05$ \\
\hline \multicolumn{7}{|c|}{ Dissolved } \\
\hline slope & 1.06 & $<0.001$ & 554.4 & $>0.05$ & 68.96 & $>0.05$ \\
\hline intercept & 611.99 & $<0.05$ & 308.2 & $>0.05$ & 65.69 & $>0.05$ \\
\hline
\end{tabular}

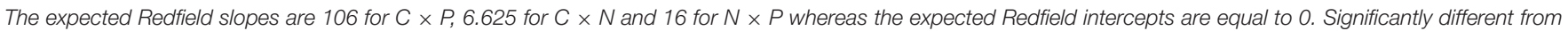
Redfield slopes and intercepts are highlighted in bold.

of 226 lakes from primarily temperate North America, and including some lakes from Europe, Africa, and Asia (Elser et al., 2000a). The mean seston C:N:P in this synthesis was 307:30:1, which is similar to the ratio that we observed in the bacterial size fraction (mean C:N:P 320:35:1) but lower than the mean values we observed in seston (C:N:P 607:108:1; Table 2). The highest seston $\mathrm{C}: \mathrm{N}$ and $\mathrm{C}: \mathrm{P}$ values were found at the lowest specific conductivities, perhaps indicating a strong terrigenous influence on the seston in the lower conductivity systems (from watershed input by rainfall).

Because our results were based on field data, numerous factors could have been affecting the stoichiometric behavior in these different lakes. Certainly, temperature is one factor that can affect seston and biomass stoichiometry (Cotner et al., 2006; Martiny et al., 2013; Phillips et al., under review) but we observed no significant differences in temperatures along the conductivity gradient (Table 1). However, there were differences in rainfall across the conductivity gradient that we observed, with greater rainfall occurring in the eastern, more oceaninfluenced region and less in the semi-arid, inland region (as description in the study area section). Our observations were made when this region was being influenced by El Nino which was one of the factors that contributed to the semi-arid region lakes experiencing an unusual prolonged drought and drastically reducing their volumes (Medeiros et al., 2015; Costa et al., 2016; Mendonça et al., in press). 

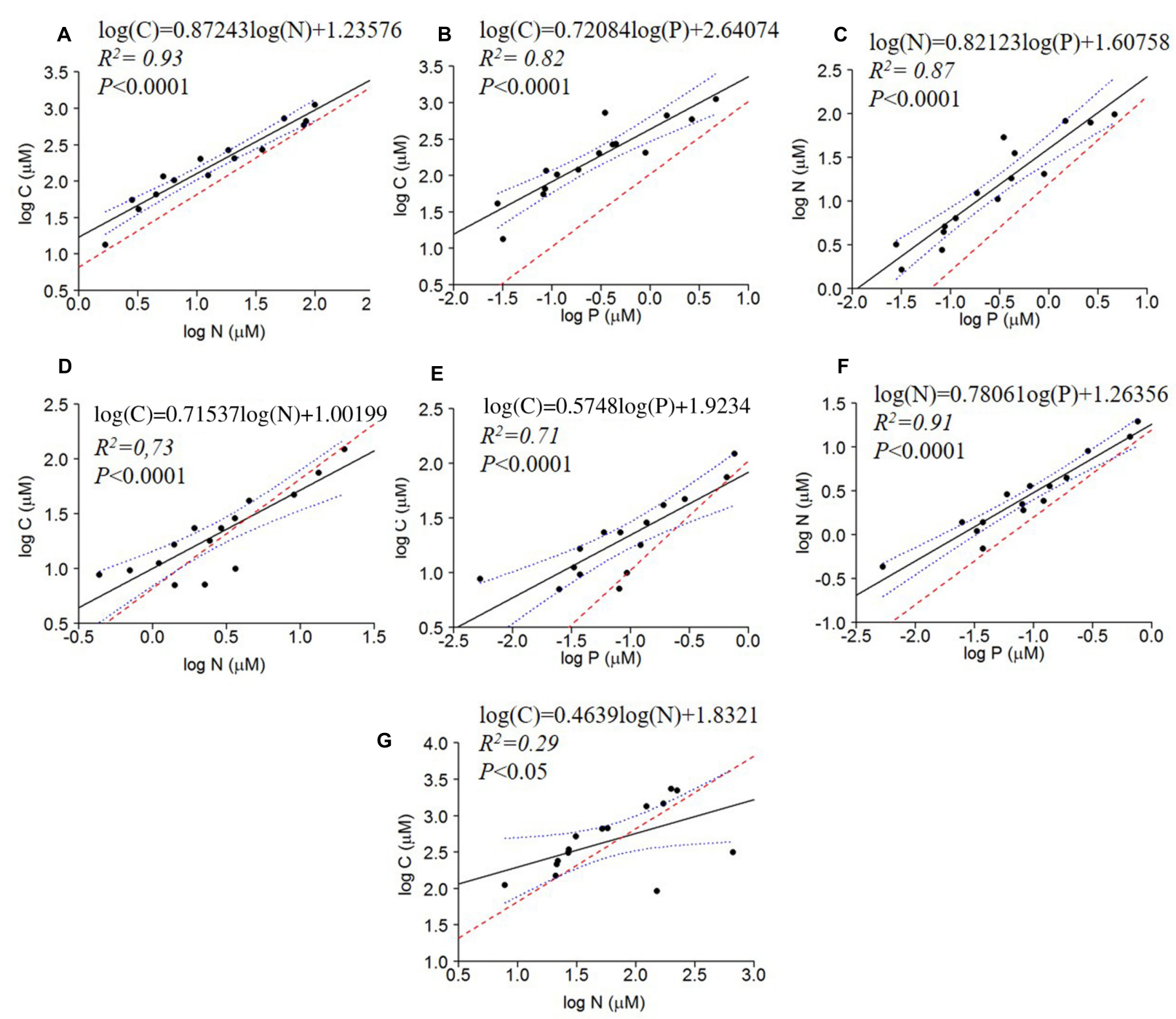

FIGURE 2 | Regressions of log of the absolute concentrations of $\mathrm{C} \times \mathrm{N}, \mathrm{C} \times \mathrm{P}$ and $\mathrm{N} \times \mathrm{P}$ of seston (A-C), bacterial (D-F) and dissolved fractions (G) compared to the Redfield ratio (dashed red line). The regression fit is indicated by black solid lines and $95 \%$ confidence intervals by blue dotted lines.

Therefore, it seems more likely that the patterns we observed between dissolved and particulate stoichiometry and specific conductivity may have been coupled to changes in residence times among the different systems. Few studies have examined relationships between water residence times and seston stoichiometry in freshwaters. One that did, however, in the Experimental Lakes of Canada (ELA), found that longer residence times correlated positively, not negatively as we found, with C:N:P (Hecky et al., 1993). Differences may have arisen from the fact that in Hecky et al.'s (1993) study a small number of lakes $(<10)$ were included and only lakes with very short residence times ( $<3$ months) were compared to longer residence time systems ( $>6$ months). Also, the lakes were not influenced by a precipitation gradient and even the long WRT lakes were oligotrophic. On the other hand, the semi-arid area lakes in our study were all human-made reservoirs built in a way that the water outflow is only possible when large inputs of water enables dam overflow, and with WRT usually greater than 24 months.

The overall pattern is a bit more complicated in freshwaters due to differences in source material that are often coupled to differences in stoichiometry. Terrestrial stoichiometric signatures tend to be higher than microbial biomass signatures due to increased concentrations of structural carbohydrates and lignin (Elser et al., 2000a; Schlesinger and Bernhardt, 2013). In lakes with short residence times, the input of terrestrial material is high and tends to dominate the organic matter composition (Cole et al., 2002; Pace et al., 2004; Wilkinson et al., 2013). However, at longer residence times, there is less input of these components and increased influence from aquatic microbes and aquatic plants. Due to more rapid growth of aquatic plants and microbes in aquatic systems and lower amounts of structural material, their stoichiometry tends to be richer in $\mathrm{N}$ and $\mathrm{P}$ (lower 

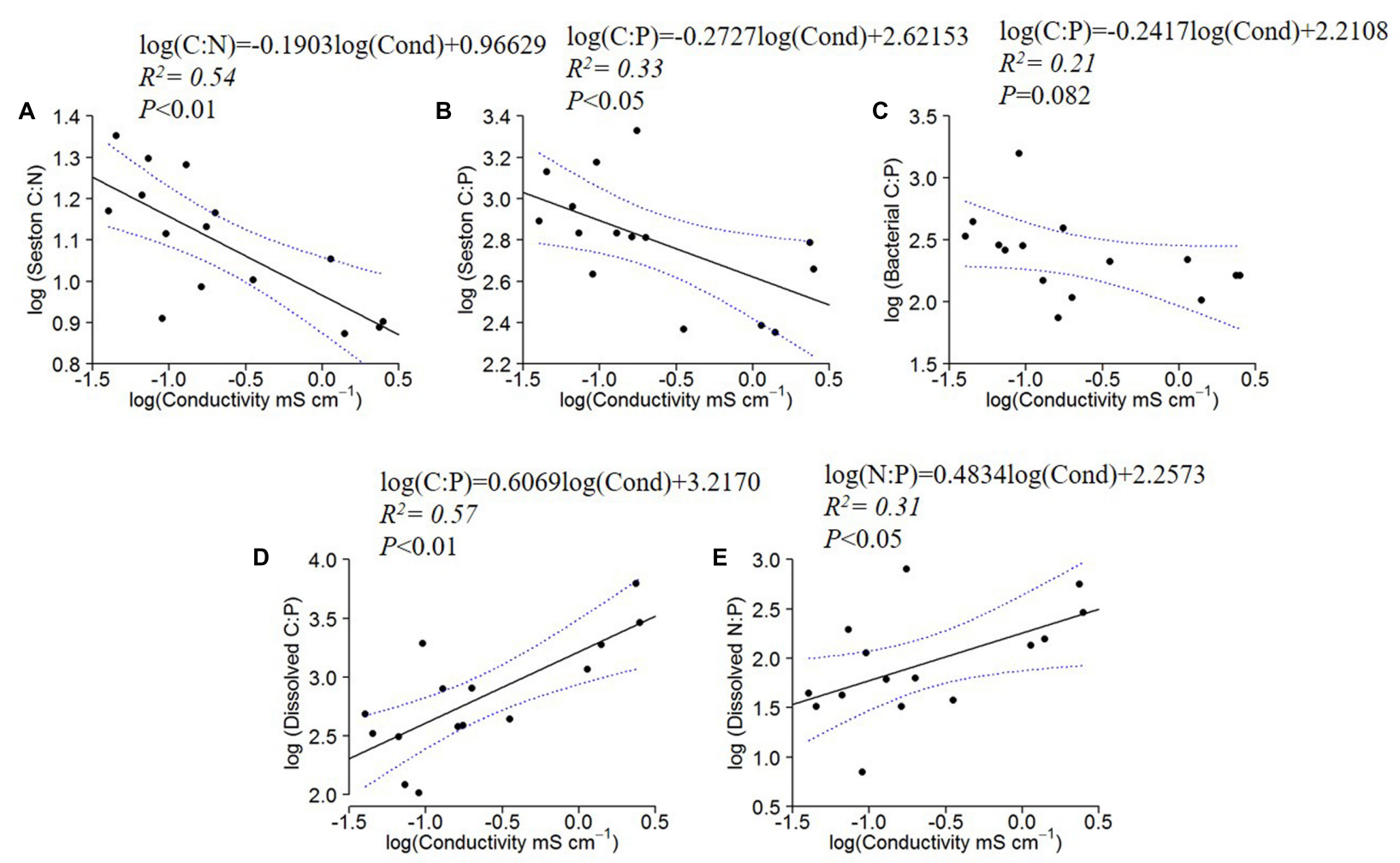

FIGURE 3 | $\log _{10}$ linear regressions of seston C:N and C:P against specific conductivity (A,B), bacterial C:P against specific conductivity (C) and dissolved C:P (D) and $\mathrm{N}: \mathrm{P}$ ratios $\mathbf{( E )}$ against specific conductivity (residence time). The regression fit is indicated by black solid lines and $95 \%$ confidence intervals by blue dotted lines.

$\mathrm{C}: \mathrm{N}$ and $\mathrm{C}: \mathrm{P})$ than terrestrial plants and they also degrade at faster rates (Enriquez et al., 1993), which means that long residence time systems should have nutrient signatures that reflect this. That seems to be the case of the lakes in the semiarid region.

Perhaps relatedly, Kellerman et al. (2014) recently demonstrated that the composition of DOM was strongly correlated with water residence times in boreal lakes. Short residence time systems had DOM composition that reflected the surrounding watershed but as residence times increased, the terrestrial signature was increasingly lost. In these boreal systems, organic matter in the longer residence time systems showed increased $\mathrm{N}$ content. The $\mathrm{N}$-containing DOM compounds were either tightly recycled or resistant to decomposition processes (Kellerman et al., 2015). Our observation of increased TDN:TDP (i.e., N:P in the dissolved fraction) ratios with specific conductivity may reflect this $\mathrm{N}$ enrichment (Figure 3E), but it is also likely that there was tight recycling of both $\mathrm{N}$ and $\mathrm{P}$ due to the limiting nature of these elements in lakes as DOC:TDP (i.e., C:P in the dissolved fraction) also increased with specific conductivity (Figure 3D).

The decreasing seston C:P, C:N and bacterial C:P with increasing conductivity indicated $\mathrm{P}$ enrichment of the organisms with increasing WRT (Figure 3). This enrichment was concomitant with increasing dissolved C:P and N:P ratios, which suggests that the plankton may have been 'mining' $\mathrm{P}$ from this dissolved pool. Although this enrichment of the particulate pool via the dissolved pool was not sufficient to bring the seston ratios to values similar to Redfield ratios, it does illustrate the central mechanism envisioned by Redfield through which planktonic organisms can modify their environment given that they are provided with sufficient residence time to process that material (Redfield, 1934; 1958). Nutrients that are not incorporated into biomass are 'discarded' to the sediments or lost to the atmosphere in the oceans. Similar dynamics are likely occurring in all lakes, but the effects are more obvious at longer residence times.

The fact that bacterial N:P ratios were positively correlated with seston N:P ratios was consistent with other studies showing a tendency for bacterial biomass to reflect some of the same stoichiometric tendencies of the larger plankton pool. In a survey of lakes in the Midwest of the United States, Cotner et al. (2010) demonstrated that the bacterial pool had stoichiometry similar to the Redfield ratio with the total seston pool showing a similar pattern, but with slightly higher C:N, C:P, and N:P ratios. Higher $\mathrm{N}$ and $\mathrm{P}$ content in the microbial pool is often attributed to higher growth rates in these organisms (Bratbak and Dundas, 1984; Makino et al., 2003; Godwin et al., 2016), but somewhat surprisingly, the stoichiometry of the bacterial and seston pools do not often differ a great deal, perhaps due to the fact that they are drawing from the same dissolved and particulate nutrient pools and/or that large portions of the microbial community are dormant (Lennon and Jones, 2011). 

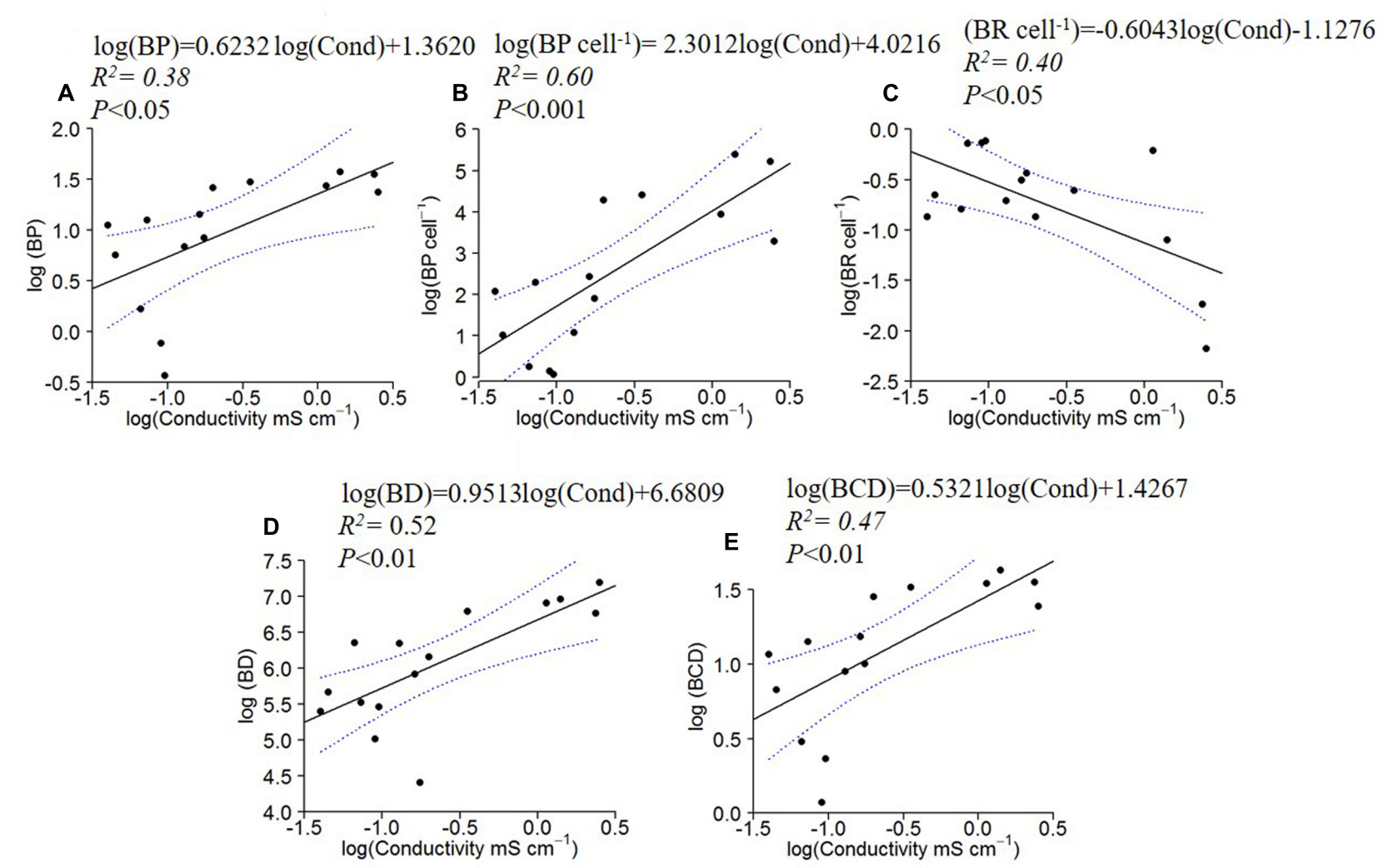

FIGURE 4 | Log $_{10}$ linear regressions of bacterial production (BP; $\left.\mathbf{A}\right)$, specific bacterial production (B) and specific bacterial respiration (C), bacterial density (BD; D) and carbon demand (BCD; E) against specific conductivity. The regression fit is indicated by black solid lines and $95 \%$ confidence intervals by blue dotted lines.

Alternatively, the bacteria could be responding positively to the seston pool due to nutrients that are being provided directly from the phytoplankton. The seston in many of these lakes is dominated by cyanobacteria and zooplankton (rotifers and copepods, Eskinazi-Sant'Anna et al., 2007). Among the cyanobacteria, several $\mathrm{N}$-fixing species like Cylindrospermopsis raciborskii, Anabaena circinalis, Aphanizomenon gracile (Fonseca et al., 2015; Medeiros et al., 2015), Microcystis aeruginosa and Oscillatoria sp. (Chellappa and Costa, 2003) have been reported to occur and dominate the phytoplankton community of these eutrophic lakes, i.e., the high WRT . The appearance/dominance of cyanobacteria in the phytoplankton community can have a strong impact in seston stoichiometry, with a tendency of lowering C:N ratios. Also, the release of dissolved organic $\mathrm{N}$-based compounds could be an important source of both organic matter and $\mathrm{N}$ for bacteria in these lakes, especially semi-arid ones during El Niño events when there are very limited external organic matter inputs (Glibert and Bronk, 1994).

Another factor contributing to lower stoichiometric ratios in the longer residence time systems could be changes in the bacterial community composition. Although we did not explicitly address this issue, $\mathrm{BD}$ and bacterial production both increased along the conductivity gradient, perhaps reflecting an increased influence of relatively rapidly growing organisms (Figure 4).
Nonetheless, there was no significant relationship between the seston-POC: bacterial-POC ratio and conductivity, suggesting that similar changes in the larger seston community may have also been occurring along the gradient. The GRH hypothesizes that rapidly growing organisms should increase their RNA and ribosome content (Elser et al., 2000b; Makino et al., 2003). Because RNA is P-rich relative to the mean composition of organisms, rapidly growing organisms should be more P-rich, with decreased C:P and N:P ratios. Recently, Godwin et al. (2017) demonstrated that the relative growth rate also plays an important role in this dynamic. Although it is difficult to assess the relative growth rate of organisms in natural environments, the increase in bacterial production and cell specific production that we observed (Figure 4) is consistent with the idea that growth rates and relative growth rates increased with increasing conductivity.

Relatedly, Goldman et al. (1979) argued that phytoplankton in the open ocean are growing at or near maximal rates because the C:P and C:N ratios are near Redfield ratios. They argued that the long residence time open ocean is much like a chemostat in that the biomass does not change much over time, yet there can be variation in nutrient supply that is drawn down by the biomass that is present with the main loss being grazing. Despite fundamental differences between open ocean and lakes, semiarid lakes become more similar to open ocean during extended 


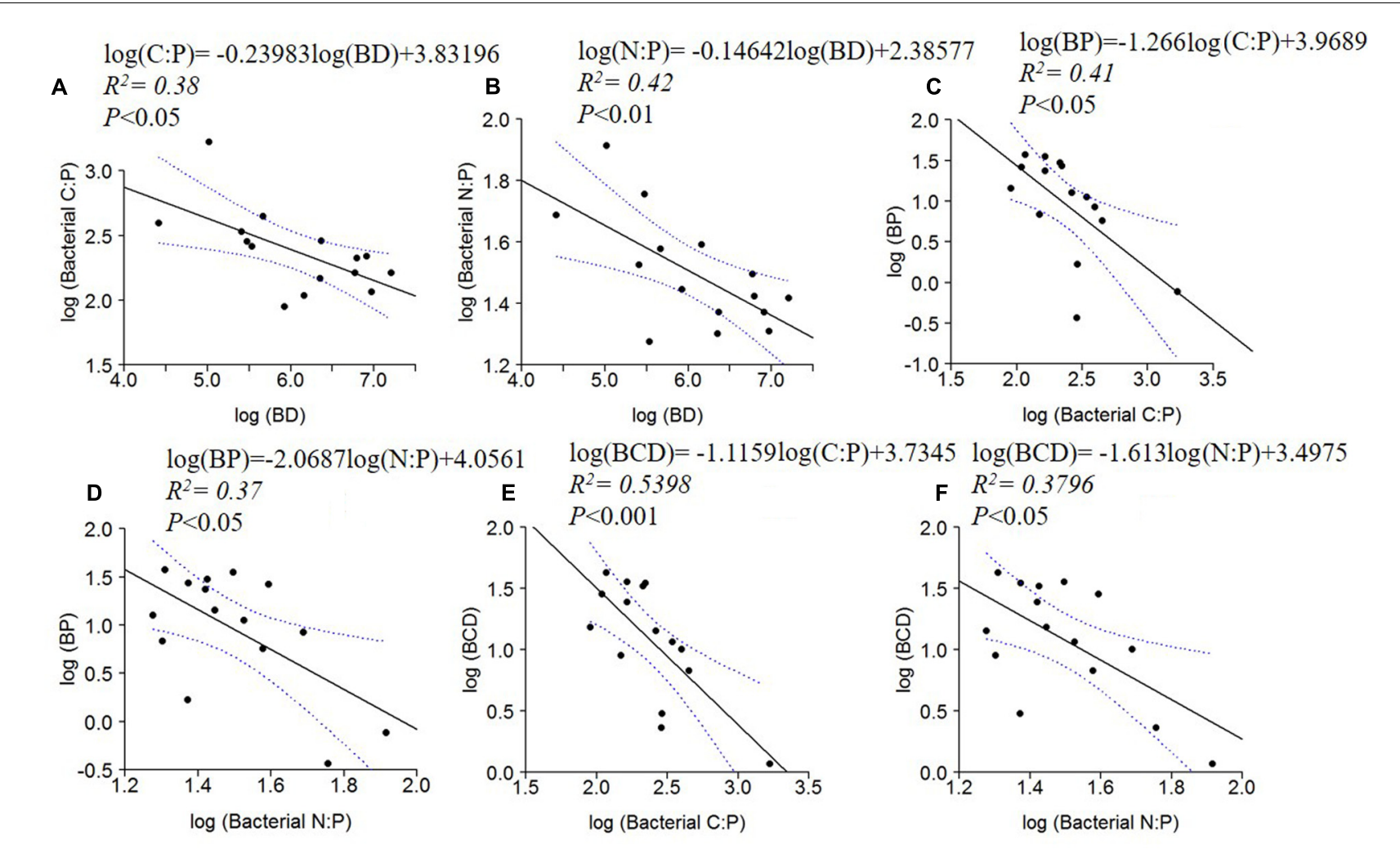

FIGURE 5 | Log $_{10}$ linear regressions of ratios of bacterial C:P (A) and N:P (B) against bacterial density (BD), BP against bacterial C:P (C) and N:P (D) and BCD against bacterial $C: P(\mathbf{E})$ and bacterial N:P (F). The regression fit is indicated by black solid lines and 95\% confidence intervals by blue dotted lines.

$$
\log (\mathrm{C}: \mathrm{P})=-0.3487 \log (\mathrm{C}: \mathrm{P})+3.3522 \quad \log (\mathrm{N}: \mathrm{P})=0.4537 \log (\mathrm{N}: \mathrm{P})+0.7228
$$
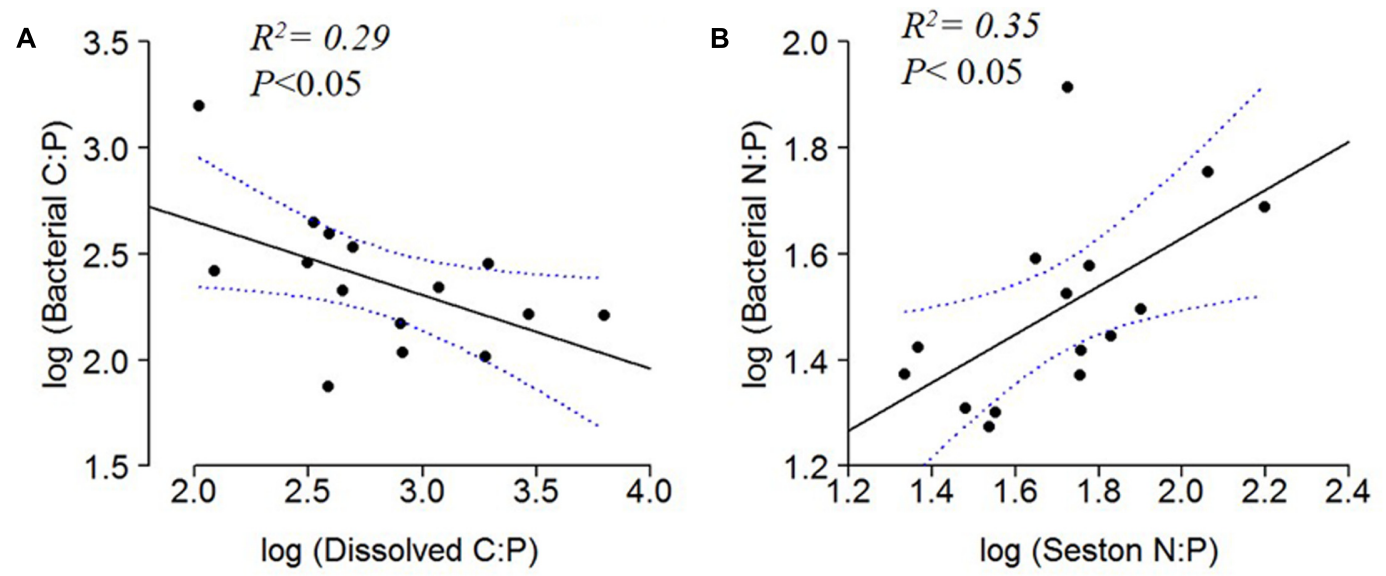

FIGURE 6 | Log $_{10}$ linear regressions of bacterial C:P against dissolved C:P (A) and bacterial N:P against seston N:P ratio (B). The regression fit is indicated by black solid lines and $95 \%$ confidence intervals by blue dotted lines.

drought periods when there is negligible input of allochthonous organic matter and the WRT increases. These lakes will likely have more variable biomass concentrations over time (still to be tested) due to greater variation in the supply rates due to episodic events such as changes in mixing depths, pulses due to storms, etc. Nevertheless, our results suggest that the mechanism envisioned by Redfield may be universal for all aquatic ecosystems under appropriate conditions. 
Even though we observed a strong effect of WRT on bacterial and seston stoichiometry in these lakes, other factors not addressed here and that may co-vary with changes in environmental conditions may also be important. Grazing pressure on bacteria by protists is stronger on larger, fast dividing cells (Sherr et al., 1992), thus potentially favoring smaller, relatively more carbon rich cells (Norland, 1993). Also, weaker top-down effects of zooplankton have also been found to favor low-quality phytoplankton, with important potential repercussions for food webs (Hessen et al., 2005).

\section{CONCLUSION}

Our observations indicated WRT can be an important factor affecting the stoichiometry of plankton in freshwater ecosystems. As WRT increased, the biomass stoichiometry of seston and the bacterial size-fraction became more enriched with $\mathrm{N}$ and $\mathrm{P}$. The dissolved organic nutrient pool stoichiometry demonstrated a negative correlation with residence time, suggesting that organic $\mathrm{N}$ and $\mathrm{P}$ pools may have been important sources of nutrients in long residence time systems. Water residence time is a parameter that has been little explored in freshwaters with respect to stoichiometry and needs to be considered in the future studies.

\section{REFERENCES}

Alonso-Sáez, L., Gasol, J. M., Arístegui, J., Vilas, J. C., Vaqué, D., Duarte, C. M., et al. (2007). Large-scale variability in surface bacterial carbon demand and growth efficiency in the subtropical northeast Atlantic Ocean. Limnol. Oceanogr. 52, 553-546. doi: 10.4319/lo.2007.52.2.0533

Andersen, T., and Hessen, D. O. (1991). Carbon, nitrogen and phosphorus content of freshwater zooplankton. Limnol. Oceanogr. 36, 807-814. doi: 10.4319/lo. 1991.36.4.0807

Anderson, N. J., and Stedmon, C. A. (2007). The effect of evapoconcentration on dissolved organic carbon concentration and quality in lakes of SW Greenland. Freshw. Biol. 52, 280-289. doi: 10.1111/j.1365-2427.2006.01688.x

APHA (1999). Standard Methods for the Examination of Water and Wastewater, 20th Edn. Washington, DC: American Public Health Association.

Bell, R. E., Studinger, M., Tikku, A. A., Clarke, G. K. C., Gutner, M. M., and Meertens, C. (2002). Origin and fate of Lake Vostok water frozen to the base of the East Antarctic ice sheet. Lett. Nat. 416, 307-310. doi: 10.1038/416307a

Bratbak, G., and Dundas, I. (1984). Bacterial dry matter content and biomass estimations. Appl. Environ. Microbiol. 48, 755-757.

Briand, E., Pringault, O., Jacquet, S., and Terréton, J. P. (2004). The use of oxygen microprobes to measure bacterial respiration for determining bacterioplankton growth efficiency. Limnol. Oceanogr 2, 406-416. doi: 10.4319/lom.2004. 2.406

Carmouze, J. P. (1994). O Metabolismo dos Ecossistemas Aquáticos - Fundamentos Teóricos, Métodos de Estudo e Análises Químicas. São Paulo: FAPESP.

Cestaro, L. A., and Soares, J. J. (2004). Variações florística e estrutural e relações fitogeográficas de um fragmento de floresta decídua no Rio Grande do Norte, Brasil. Acta Bot. Brasilica 18, 203-218. doi: 10.1590/S0102-33062004000200001

Chellappa, N. T., Chellappa, T., Câmara, F. R. A., Rocha, O., and Chellappa, S. (2009). Impact of stress and disturbance factors on the phytoplankton communities in Northeastern Brazil reser- voir. Limnologica 39, 273-282. doi: 10.1016/j.limno.2009.06.006

Chellappa, N. T., and Costa, M. A. M. (2003). Dominant and co-existing species of Cyanobacteria from a eutrophicated reservoir of Rio Grande do Norte State, Brazil. Acta Oecol. 24, S3-S10. doi: 10.1016/S1146-609X(03)00005-5

\section{AUTHOR CONTRIBUTIONS}

NT Performed field and lab work and writing. AA planned, performed field and lab work and contributed to the writing. JC planned, performed field and lab work and contributed to the writing.

\section{FUNDING}

This work was partially supported by a grant to JC from NSF (IOS No. 1257571) and by a grant to AA from CAPES (PVE No. 88881.030384/2013-01).

\section{ACKNOWLEDGMENTS}

The authors thank B. Wanderley, V. Ferreira, C. Godwin and A. Little for field and laboratory support.

\section{SUPPLEMENTARY MATERIAL}

The Supplementary Material for this article can be found online at: http://journal.frontiersin.org/article/10.3389/fmicb. 2017.01505/full\#supplementary-material

Cimbleris, A. C. P., and Kalff, J. (1998). Planktonic bacterial respiration as a function of C:N:P ratios across temperate lakes. Hydrobiologia 384, 89-100. doi: 10.1023/A:1003496815969

Cole, J. J., Carpenter, S. R., Kitchell, J. F., and Pace, M. L. (2002). Pathways of organic carbon utilization in small lakes: results from a whole-lake C-13 addition and coupled model. Limnol. Oceanogr. 47, 1664-1675. doi: 10.4319/ lo.2002.47.6.1664

Costa, M. R. A., Attayde, J. L., and Becker, V. (2016). Effects of water level reduction on the dynamics of phytoplankton functional groups in tropical semi-arid shallow lakes. Hydrobiologia 778, 75-89. doi: 10.1007/s10750-0152593-6

Cotner, J. B., and Biddanda, B. A. (2002). Small players, large role: microbial influence on biogeochemical processes in pelagic aquatic ecosystems. Ecosystems 5, 105-121. doi: 10.1007/s10021-001-0059-3

Cotner, J. B., Hall, E. K., Scott, J. T., and Heldal, M. (2010). Freshwater bacteria are stoichiometrically flexible with a nutrient composition similar to seston. Front. Microbiol. 1:132. doi: 10.3389/fmicb.2010.00132

Cotner, J. B., Makino, W., and Biddanda, B. (2006). Temperature affects stoichiometry and biochemical composition of Escherichia coli. Microb. Ecol. 52, 26-33. doi: 10.1007/s00248-006-9040-1

Cotner, J. B., and Wetzel, R. G. (1992). Uptake of dissolved inorganic and organic phosphorus compounds by phytoplankton and bacterioplankton. Limnol. Oceanogr. 37, 232-243. doi: 10.4319/lo.1992.37.2.0232

Curtis, P. J., and Adams, H. E. (1995). Dissolved organic matter quantity and quality from freshwater and saltwater lakes in east-central Alberta. Biogeochemistry 30, 59-76. doi: 10.1007/BF02181040

Elser, J. J., Dobberfuhl, D. R., MacKay, N. A., and Schampel, J. H. (1996). Organism size, life history, and N:P stoichiometry. Bioscience 46, 674-684. doi: 10.2307/ 1312897

Elser, J. J., Fagan, W. F., Denno, R. F., Dobberfuhl, D. R., Folarin, A., Huberty, A., et al. (2000a). Nutritional constraints in terrestrial and freshwater food webs. Nature 408, 578-580.

Elser, J. J., Sterner, R. W., Gorokhova, E., Fagan, W. F., Markow, T. A., Cotner, J. B., et al. (2000b). Biological stoichiometry from genes to ecosystems. Ecol. Lett. 3, 540-550. doi: 10.1046/j.1461-0248.2000.00185.x 
Enriquez, S., Duarte, C. M., and Sandjensen, K. (1993). Patterns in decomposition rates among photosynthetic organisms: the importance of detritus C:N:P content. Oecologia 94, 457-471. doi: 10.1007/BF00566960

Eskinazi-Sant'Anna, E. M., Menezes, R., Costa, I. S., Panosso, R. F., Araújo, M. F., and Attayde, J. L. (2007). Composição da comunidade zooplanctônica em reservatórios eutróficos do semi-árido do Rio Grande do Norte. Oecol. Brasiliensis 11, 410-421. doi: 10.4257/oeco.2007. 1103.10

Falkowski, P. G., and Davis, C. S. (2004). Redfield ratios: the uniformity of elemental ratios in the oceans and life they contain underpins our understanding of marine biogeochemistry. Nature 431:131. doi: 10.1038/ 431131a

Fonseca, J. R., Vieira, P. C. S., Kujbida, P., and Costa, I. A. S. (2015). Cyanobacterial occurrence and detection of microcystins saxitoxins in reservoirs of the Brazilian semi-arid. Acta Limnol. Brasiliensia 27, 78-92. doi: 10.1590/S2179975X2814

Gasol, J. M., and Del Giorgio, P. A. (2000). Using flow cytometry for counting natural planktonic bacteria and understanding the structure of planktonic bacterial communities. Sci. Mar. 64, 197-224. doi: 10.3989/scimar.2000. $64 \mathrm{n} 2197$

Gasol, J. M., del Giorgio, P. A., and Duarte, C. M. (1997). Biomass distribution in marine planktonic communities. Limnol. Oceanogr. 42, 1353-1363. doi: 10.4319/lo.1997.42.6.1353

Geider, R. J., and La Roche, J. (2002). Redfield revisited: variability of C:N:P in marine microalgae and its biochemical basis. Eur. J. Phycol. 37, 1-17. doi: $10.1017 /$ S0967026201003456

Glibert, P. M., and Bronk, D. A. (1994). Release of dissolved organic nitrogen by marine diazotrophic cyanobacteria, Trichodesmium spp. Environ. Microbiol. 60, 3996-4000.

Glöckner, F. O., Fuchs, B. M., and Amann, R. (1999). Bacterioplankton compositions of lakes and oceans: a first comparison based on fluorescence in situ hybridization. Appl. Environ. Microbiol 65, 3721-3726.

Godwin, C. M., and Cotner, J. B. (2015). Aquatic hetrotrophic bacteria have highly flexible phosphorus content and biomass stoichiometry. ISME J. 9, 2324-2327. doi: 10.1038 /ismej.2015.34

Godwin, C. M., Whitaker, E. A., and Cotner, J. B. (2016). Growth rate and resource imbalance interactively control biomass stoichiometry and elemental quotas of aquatic bacteria. Ecology 98, 820-829. doi: 10.1002/ecy.1705

Godwin, C. M., Whitaker, E. A., and Cotner, J. B. (2017). Growth rate and resource imbalance interactively control biomass stoichiometry and elemental quotas of aquatic bacteria. Ecology 98, 820-829. doi: 10.1002/ecy.1705

Goldman, J. C., McCarthy, J. J., and Peavey, D. G. (1979). Growth rate influence on the chemical composition of phytoplankton in oceanic waters. Nature 279, 210-215. doi: 10.1038/279210a0

Gruber, N., and Deutsch, C. A. (2014). Redfield's evolving legacy. Nat. Geosci. 7, 853-855. doi: 10.1038/ngeo2308

Hassett, R. P., Cardinale, B., Stabler, L. B., and Elser, J. J. (1997). Ecological stoichiometry of $\mathrm{N}$ and $\mathrm{P}$ in pelagic ecosystems: comparison of lakes and oceans with emphasis on the zooplankton-phytoplankton interaction. Limnol. Oceanogr. 42, 648-662. doi: 10.4319/lo.1997.42.4.0648

Hecky, R. E., Campbell, P., and Hendzel, L. (1993). The stoichiometry of carbon, nitrogen, and phosphorus in particulate matter of lakes and oceans. Limnol. Oceanogr. 38, 709-724. doi: 10.4319/lo.1993.38.4.0709

Hessen, D. O. (2006). Determinants of seston C: P-ratio in lakes. Freshw. Biol. 51, 1560-1569. doi: 10.1111/j.1365-2427.2006.01594.x

Hessen, D. O., Andersen, T., Brettum, P., and Faafeng, A. (2003). Phytoplankton contribution to sestonic mass and elemental ratios in lakes: implications for zooplankton nutrition. Limnol. Oceanogr. 48, 1289-1296. doi: 10.4319/lo.2003. 48.3.1289

Hessen, D. O., and Anderson, T. R. (2008). Excess carbon in aquatic organisms and ecosystems: physiological, ecological, and evolutionary implications. Limnol. Oceanogr. 53, 1685-1696. doi: 10.4319/lo.2008.53.4.1685

Hessen, D. O., Donk, E. V., and Gulati, R. (2005). Seasonal seston stoichiometry: effects on zooplankton in cyanobacteria:dominated lakes. J. Plankton Res. 27, 449-460. doi: 10.1093/plankt/fbi018

Hessen, D. O., Færovig, P. J., and Andersen, T. (2002). Light, nutrients, and P:C ratios in algae: grazer performance related to food quality and quantity. Ecology 83, 1886-1898. doi: 10.1890/0012-9658(2002)083[1886:LNAPCR]2.0.CO;2
Kasting, J. F., and Siefert, J. L. (2002). Life and evolution of Earth's atmosphere. Science 296, 1066-1068. doi: 10.1126/science.1071184

Kellerman, A. M., Dittmar, T., Kothawala, D. N., and Tranvik, L. J. (2014). Chemodiversity of dissolved organic matter in lakes driven by climate and hydrology. Nat. Commun. 5:3804. doi: 10.1038/ncomms4804

Kellerman, A. M., Kothawala, D. N., Dittmar, T., and Tranvik, L. J. (2015). Persistence of dissolved organic matter in lakes related to its molecular characteristics. Nat. Geosci. 8, 454-457. doi: 10.1038/ngeo2440

Kirchman, D. L. (1994). The uptake of inorganic nutrients by heterotrophic bacteria. Microb. Ecol. 28, 255-271. doi: 10.1007/BF00166816

Koeve, W., and Kähler, P. (2010). Balancing ocean nitrogen. Nat. Geosci. 3, 383-384. doi: 10.1038/ngeo884

Kosten, S., Roland, F., Marques, D., Van Nes, E. H., Mazzeo, N., Sternberg, L. D. L., et al. (2010). Climate-dependent CO2 emissions from lakes. Glob. Biogeochem. Cycles 24:GB2007.

Kottek, M., Grieser, J., Beck, C., Rudolf, B., and Rubel, F. (2006). World map of the Koppen-Geiger climate classification updated. Meteorol. Z. 15, 259-263. doi: $10.1127 / 0941-2948 / 2006 / 0130$

Lennon, J. T., and Jones, S. E. (2011). Microbial seed banks: the ecological and evolutionary implications of dormancy. Nat. Rev. Microbiol. 9, 119-130. doi: $10.1038 /$ nrmicro 2504

Mackereth, F. J. H., Heron, J., and Talling, J. F. (1978). Water Analysis: Some Revised Methods for Limnologists. Ambleside: Freshwater Biological Association.

Makino, W., Cotner, J. B., Sterner, R. W., and Elser, J. J. (2003). Are bacteria more like plants or animals? Growth rate and resource dependence of bacterial C : N : P stoichiometry. Funct. Ecol. 17, 121-130. doi: 10.1046/j.1365-2435.2003. 00712.x

Martiny, A. C., Pham, C. T. A., Primeau, F. W., Vrugt, J. A., Moore, J. K., Levin, S. A., et al. (2013). Strong latitudinal patterns in the elemental ratios of marine plankton and organic matter. Nat. Geosci. 6, 279-283. doi: 10.1038/ngeo1757

McGroody, M. E., Daufresne, T., and Hedin, L. O. (2004). Scaling of C:N:P stoichiometry in forests worldwide: implications of terrestrial redfield-type ratios. Ecology 85, 2390-2401. doi: 10.1890/03-0351

Medeiros, L. C., Mattos, A., Lürling, M., and Becker, V. (2015). Is the future bluegreen or brown? The effects of extreme events on phytoplankton dynamics in semi-arid man-made lake. Aquat. Ecol. 49, 293-307. doi: 10.1007/s10452-0159524-5

Mendonça, J. R., Amado, M. A., and Becker, V. (in press). Extreme droughts drive tropical semi-arid eutrophic reservoirs towards $\mathrm{CO} 2$ sub-saturation. Acta Limnol. Brasil.

Norland, S. (1993). "The relationship between biomass and volume of bacteria," in Handbook of Methods in Aquatic Microbial Ecology, eds P. F. Kemp, B. F. Sherr, E. B. Sherr, and J. J. Cole (Boca Raton, FL: Lewis Publishers), 339-345.

Nusch, E. A., and Palme, G. (1975). Biologische methoden für die praxis der gewisseruntersuchung 1. Bestimmung des chlorophyll a und phaeopigmentgehaltes in oberflachenwasser. GWF 116, 562-565.

Pace, M. L., Cole, J. J., Carpenter, S. R., Kitchell, J. F., Hodgson, J. R., Van De Bogert, M. C., et al. (2004). Whole-lake carbon-13 additions reveal terrestrial support of aquatic food webs. Nature 427, 240-243. doi: 10.1038/nature02227

Pena, E. A., and Slate, E. H. (2014). gvlma: Global Validation of Linear Models Assumptions. Available at: http://CRAN.R-project.org/package=gvlma

Persson, J., Fink, P., Hood, J. M., Jonas, J., and Kato, S. (2010). To be or not to be what you eat: regulation of stoichiometric homeostasis among autotrophs and heterotrophs. Oikos 119, 741-751. doi: 10.1111/j.1600-0706.2009.18545.x

R Core Team (2016). R: A Language and Environment for Statistical Computing Author R Foundation for Statistical Computing. Available at: https://www.Rproject.org

Redfield, A. C. (1934). "On the proportions of organic derivatives in the sea water and their relation to the composition of plankton," in James Johnstone Memorial Volume, ed. R. J. Daniel (Liverpool: University Press of Liverpool), 176-192.

Redfield, A. C. (1958). The biological control of chemical factors in the environment. Am. Sci. 46, 205-221.

Rennella, A. M., and Quirós, R. (2006). The effects of hydrology on plankton biomass in shallow lakes of the Pampa Plain. Hydrobiologia 556, 181-191. doi: 10.1007/s10750-005-0318-y

Rodrigues, R. R., Haarsma, R. J., Campos, E. J. D., and Ambrizzi, T. (2011). The impacts of inter-El Niño variability on the tropical atlantic and northeast Brazil climate. J. Clim. 24, 3402-3422. doi: 10.1175/2011JCLI3983.1 
Salonen, K., and Sarvala, J. (1995). Field Manual for the Determination of Chlorophyll a, and Primary Production in the Lake Tanganyika Research. Rome: FAO, 14.

Sarmento, H., Unrein, F., Isumbisho, M., Stenuite, S., Gasol, J. M., and Descy, J.-P. (2008). Abundance and distribution of picoplankton in tropical, oligotrophic Lake Kivu, eastern Africa. Freshw. Biol. 53, 756-771. doi: 10.1111/j.1365-2427. 2007.01939.x

Saunders, D. L., and Kalff, J. (2001). Nitrogen retention times in wetlands, lakes and rivers. Hydrobiologia 443, 205-212. doi: 10.1023/A:10175069 14063

Schilling, P., Powilleit, M., and Uhlig, S. (2006). Chlorophyll a determination: results of an interlaboratory comparison. Accred. Qual. Assur. 11, 462-469. doi: 10.1007/s00769-006-0158-0

Schlesinger, W. H., and Bernhardt, E. S. (2013). Biogeochemistry: An Analysis of Global Change. Cambridge, MA: Academic Press. doi: 10.1093/obo/ 9780199830060-0111

Sherr, B. F., Sherr, E. B., and McDaniel, J. (1992). Effect of protistan grazing on the frequency of dividing cells in bacterioplankton assemblages. Appl. Environ. Microbiol. 58, 2381-2385.

Simon, M. (1987). Biomass and production of small and large free-living and attached bacteria in Lake constance. Limnol. Oceanogr. 32, 591-607. doi: 10.1007/BF02011709

Simon, M., Cho, B. C., and Azam, F. (1992). Significance of bacterial biomass in lakes and the ocean: comparison to phytoplankton biomass and biogeochemical implications. Mar. Ecol. Progr. Ser. 86, 103-110. doi: 10.3354/meps 086103

Smith, D. C., and Azam, F. (1992). A simple, economical method for measuring bacterial protein synthesis rates in sea water using $3 \mathrm{H}$-leucine. Mar. Microbial. Food Webs 6, 107-114
Sonzogni, W. C., Uttormark, P. C., and Lee, G. F. (1976). A phosphorus residence time model: theory and application. Water Res. 10, 429-435. doi: 10.1016/00431354(76)90061-0

Sterner, R. W., Andersen, T., Elser, J. J., Hessen, D. O., Hood, J. M., McCauley, E., et al. (2008). Scale-dependent carbon:nitrogen:phosphorus seston stoichiometry in marine and freshwaters. Limnol. Oceanogr. 53, 1169-1180. doi: 10.4319/lo.2008.53.3.1169

Sterner, R. W., and Elser, J. J. (2002). Ecological Stoichiometry: The Biology of Elements from Molecules to the Biosphere. Princeton, NJ: Princeton University Press, 438.

Sterner, R. W., Elser, J. J., Fee, E. J., Guildford, S. J., and Chrzanowski, T. H. (1997). The light: nutrient ratio in lakes: the balance of energy and materials affects ecosystem structure and process. Am. Nat. 150, 663-684. doi: 10.1086/286088

Wetzel, R. G. (1984). Detrital dissolved and particulate organic carbon functions in aquatic ecosystems. Bull. Mar. Sci. 35, 503-509.

Wilkinson, G. M., Pace, M. L., and Cole, J. J. (2013). Terrestrial dominance of organic matter in north temperate lakes. Glob. Biogeochem. Cycles 27, 43-51. doi: 10.1029/2012GB004453

Conflict of Interest Statement: The authors declare that the research was conducted in the absence of any commercial or financial relationships that could be construed as a potential conflict of interest.

Copyright (C) 2017 They, Amado and Cotner. This is an open-access article distributed under the terms of the Creative Commons Attribution License (CC BY). The use, distribution or reproduction in other forums is permitted, provided the original author(s) or licensor are credited and that the original publication in this journal is cited, in accordance with accepted academic practice. No use, distribution or reproduction is permitted which does not comply with these terms. 